Keywords: Tank 50

Waste Acceptance Criteria Saltstone

Retention: Permanent

\title{
Results for the Fourth Quarter 2010 Tank 50 WAC Slurry Sample: Chemical and Radionuclide Contaminant Results
}

M.M. Reigel

February 2011

Savannah River National Laboratory Savannah River Nuclear Solutions Aiken, SC 29808

Prepared for the U.S. Department of Energy under contract number DE-AC09-08SR22470.

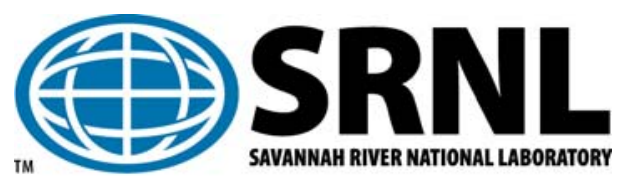


SRNL-STI-2010-00713

Revision 0

\section{DISCLAIMER}

This work was prepared under an agreement with and funded by the U.S. Government. Neither the U.S. Government or its employees, nor any of its contractors, subcontractors or their employees, makes any express or implied:

1. warranty or assumes any legal liability for the accuracy, completeness, or for the use or results of such use of any information, product, or process disclosed; or

2. representation that such use or results of such use would not infringe privately owned rights; or

3. endorsement or recommendation of any specifically identified commercial product, process, or service.

Any views and opinions of authors expressed in this work do not necessarily state or reflect those of the United States Government, or its contractors, or subcontractors.

\section{Printed in the United States of America \\ Prepared for \\ U.S. Department of Energy}




\section{REVIEWS AND APPROVALS}

AUTHORS:

M.M. Reigel, Engineering Process Development

Date

TECHNICAL REVIEW:

C.C. DiPrete, Analytical Development

Date

APPROVAL:

A.B. Barnes, Manager

Date

Engineering Process Development

S.L. Marra, Manager

Date

Environmental \& Chemical Process Technology Research Programs

J.E. Occhippinti, Manager

Date

Waste Solidification Engineering

A.W. Wiggins, Manager

Date

LWO Process Chemistry 


\section{EXECUTIVE SUMMARY}

This report details the chemical and radionuclide contaminant results for the characterization of the 2010 Fourth Quarter sampling of Tank 50 for the Saltstone Waste Acceptance Criteria (WAC). ${ }^{1}$ Information from this characterization will be used by Liquid Waste Operations (LWO) to support the transfer of low-level aqueous waste from Tank 50 to the Salt Feed Tank in the Saltstone Facility in Z-Area, where the waste will be immobilized. This information is also used to update the Tank 50 Waste Characterization System.

The following conclusions are drawn from the analytical results provided in this report:

- The concentrations of the reported chemical and radioactive contaminants were less than their respective WAC targets or limits unless noted in this section.

- The reported detection limits for ${ }^{94} \mathrm{Nb},{ }^{247} \mathrm{Cm}$ and ${ }^{249} \mathrm{Cf}$ are above the requested limits from Reference 2. However, they are below the limits established in Reference 3.

- There is an estimated concentration of trimethylbenzene $(2.25 \mathrm{mg} / \mathrm{L})$. This is not a WAC analyte, but it is the first time this organic compound has been detected in a quarterly WAC sample from Tank 50.

- The reported detection limit ${ }^{4}$ for Norpar 13 is greater than the limit from Table 4 and Attachment 8.2 of the WAC ${ }^{1}$.

- The reported detection limit for Isopar L is greater than the limit from Table 3 of the $\mathrm{WAC}^{1}$.

- Isopar L and Norpar 13 have limited solubility in aqueous solutions making it difficult to obtain consistent and reliable sub-samples. The values reported in this memo are the concentrations in the sub-sample as detected by the GC/MS; however, the results may not accurately represent the concentrations of the analytes in Tank 50. 


\section{TABLE OF CONTENTS}

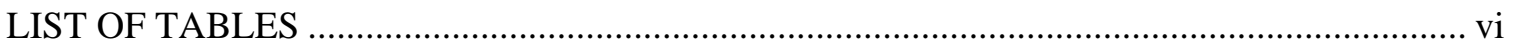

LIST OF ABBREVIATIONS ............................................................................................... vii

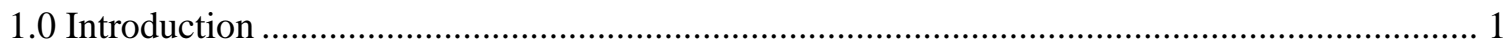

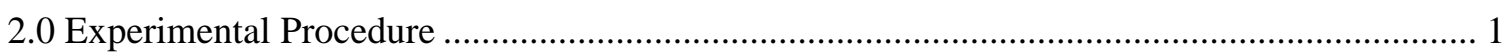

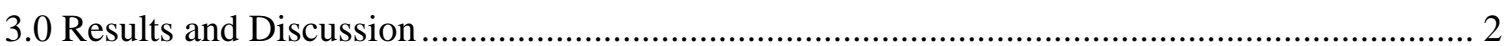

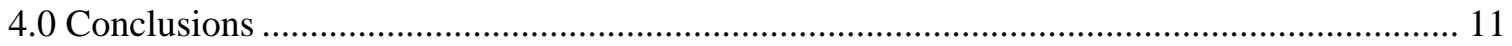

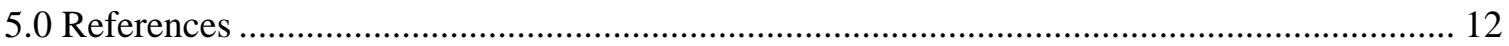


SRNL-STI-2010-00713

Revision 0

\section{LIST OF TABLES}

Table 3-1. Results for the 4th Quarter 2010 Tank 50 Slurry Samples for Chemical Contaminants Listed in Attachment 8.1 of the Saltstone WAC.

Table 3-2. Results for the 4th Quarter 2010 Tank 50 Slurry Samples for Chemical Contaminants Listed in Attachment 8.2 of the Saltstone WAC.................................................................... 4

Table 3-3. Results for 4th Quarter 2010 Tank 50 Slurry Samples and WAC Limits for Radionuclide Contaminants Listed in Attachment 8.3 of the Saltstone WAC......................... 5

Table 3-4. Results for 4th Quarter 2010 Tank 50 Slurry Samples and WAC Targets for Radionuclide Contaminants Listed in Attachment 8.4 of the Saltstone WAC..... 5

Table 3-5. Results for the 4th Quarter 2010 Tank 50 Slurry Samples for Acceptance Criteria Limits for Chemical Contaminants Impacting Vault Flammability, Listed in Table 3 of the Saltstone WAC.

Table 3-6. Results for the 4th Quarter 2010 Tank 50 Slurry Samples for Concentrations of "Other Organics” Impacting Vault Flammability, Listed in Table 4 of the Saltstone WAC............... 7

Table 3-7. Results for the 4th Quarter 2010 Tank 50 Slurry Samples for Saltstone Processing Criteria WAC Limits, Listed in Table 5 of the Saltstone WAC.

Table 3-8. Requests for Constituents for TCLP/UHC Support as well as from the TTR for Tank 50 Slurry Samples; Results Not Contained in Previous Tables.

Table 3-9. Requests from the WSE for Corrosion Species from Tank 50 Slurry Samples; Results Not Contained in Previous Tables..................................................................................... 9

Table 3-10. Additional Radionuclides Requested for Inventory Reporting Requirements. 10 


\section{LIST OF ABBREVIATIONS}

\begin{tabular}{|c|c|}
\hline AA & Atomic Absorption (spectroscopy) \\
\hline $\mathrm{AD}$ & Analytical Development \\
\hline ARP/MCU & Actinide Removal Process/Modular CSSX Unit \\
\hline CLFL & Composite Lower Flammability Limit \\
\hline CSSX & Caustic Side Solvent Extraction \\
\hline DDA & Deliquification, Dissolution and Adjustment \\
\hline EPA & Environmental Protection Agency \\
\hline ETP & Effluent Treatment Project \\
\hline GC/MS & Gas Chromatograph/Mass Spectrometer \\
\hline HDPE & High Density Polyethylene \\
\hline HPLC & High Performance Liquid Chromatography \\
\hline IC & Ion Chromatography \\
\hline ICP-ES & Inductively coupled plasma - (atomic) emission spectroscopy \\
\hline ICP-MS & Inductively coupled plasma - mass spectroscopy \\
\hline $\mathrm{L}$ & Liter \\
\hline LLW & Low Level Waste \\
\hline LSC & Liquid Scintillation Counting \\
\hline LWO & Liquid Waste Operations \\
\hline MDL & Method Detection Limit \\
\hline MRL & Method Reporting Limit \\
\hline $\mathrm{mg}$ & Milligram \\
\hline $\mathrm{mL}$ & Milliliter \\
\hline ND & Not Determined \\
\hline $\mathrm{pCi} / \mathrm{mL}$ & Picocurie per milliliter \\
\hline RSD & Relative Standard Deviation \\
\hline $\mathrm{SC}$ & Shielded Cells (Facility) \\
\hline SDF & Saltstone Disposal Facility \\
\hline SFT & Salt Feed Tank \\
\hline SPF & Saltstone Production Facility \\
\hline SRNL & Savannah River National Laboratory \\
\hline SRS & Savannah River Site \\
\hline SVOA & Semi-volatile Organic Analysis \\
\hline TCLP/UHC & $\begin{array}{l}\text { Toxic Characterization Leaching Procedure/Underlying Hazardous } \\
\text { Constituent }\end{array}$ \\
\hline
\end{tabular}




$\begin{array}{ll}\text { TIC } & \text { Tentatively Identifiable Compound } \\ \text { TIC/TOC } & \text { Total inorganic carbon/total organic carbon } \\ \text { TTQAP } & \text { Task Technical and Quality Assurance Plan } \\ \text { TTR } & \text { Technical Task Request } \\ \text { VOA } & \text { Volatile organic analysis } \\ \text { WAC } & \text { Waste Acceptance Criteria } \\ \text { WCS } & \text { Waste Characterization System } \\ \text { WSE } & \text { Waste Solidification Engineering } \\ \text { WT \% } & \text { Weight percent }\end{array}$




\subsection{Introduction}

The Saltstone Facility is designed and permitted to immobilize and dispose of low-level radioactive and hazardous liquid waste (salt solution) remaining from the processing of radioactive material at the Savannah River Site. ${ }^{1}$ Low-level waste (LLW) streams from the Effluent Treatment Project (ETP), H-Canyon, the DDA (Deliquification, Dissolution, and Adjustment) process, and the decontaminated salt solution product from the Actinide Removal Process/Modular Caustic Side Solvent Extraction (CSSX) Unit (ARP/MCU) process are stored in Tank 50 until the LLW can be transferred to the Saltstone Facility for treatment and disposal. The LLW must meet the specified waste acceptance criteria (WAC) before it is processed into saltstone. ${ }^{1}$ The specific chemical and radionuclide contaminants and their respective WAC limits are listed in the current Saltstone WAC. ${ }^{1}$

SRS Liquid Waste Operations (LWO) requested that Savannah River National Laboratory (SRNL) perform quarterly analysis on saltstone samples. ${ }^{5}$ The concentrations of chemical and radionuclide contaminants are measured to ensure the saltstone produced during each quarter is in compliance with the current WAC. ${ }^{1,2,5,6}$ This report documents the concentrations of chemical and radionuclide contaminants for the 2010 Fourth Quarter samples collected from Tank 50 on October 4, 2010 and discusses those results in further detail than the previously issued results report. $^{7}$

\subsection{Experimental Procedure}

On October 4, 2010, six 200-mL samplers (HTF-50-10-134, -135, -136, -137, -138, -139) were collected from Tank 50 for Fourth Quarter 2010 WAC analyses and delivered to the SRNL Shielded Cells (SC).

At SRNL, slurry samples ( 10 mL each) from HTF-50-10-134 were transferred to glass vials with Teflon-lined caps. The vials were completely filled to minimize the void space and the volatilization of organics. The aliquots were transferred to the Analytical Development (AD) Organic Analysis Laboratory for semi-volatile and volatile organic analysis (SVOA and VOA respectively). Four additional $10-\mathrm{mL}$ aliquots (for duplicate analyses) were used for SVOA analysis to determine the concentration of Isopar L and Norpar 13, respectively in the sample.

After the samples for organic analyses were obtained, the slurries in the steel samplers were combined into a 2-L high density polyethylene (HDPE) bottle according to the following procedure. Each steel sampler was agitated to disperse any solids in the slurry. After mixing the slurry in the steel sampler, the slurry was transferred to the 2-L HDPE bottle. The transferred slurry was left to settle. A portion of the clear supernate was returned to each steel sampler, mixed to mobilize any remaining solids, and again returned to the 2-L HDPE bottle. Visual inspection of the inside of each $200-\mathrm{mL}$ sampler indicated there were no visible solids remaining in the samplers. The total weight of the transferred slurry was approximately 932 grams.

The 2-L HDPE bottle was agitated to thoroughly mix the solids into the supernate. Aliquots of slurry samples were promptly collected with slurry pipettes to minimize settling effects and placed in HDPE bottles. A three milliliter sample of the slurry was used to determine the density of the slurry. 
Slurry samples were submitted in triplicate to AD laboratories for the following analyses:

- Six-mL aliquots to the AD Ion Chromatography (IC) Laboratory for soluble anion analyses and soluble cation analyses.

- Six-mL aliquots to the AD Organic Analysis Laboratory for measurement of tetraphenlyborate and ethylenediaminetetraacetic acid by high performance liquid chromatography (HPLC).

- Six-mL aliquots to the AD Wet Chemistry Laboratory for Total Inorganic Carbon/ Total Organic Carbon (TIC/TOC) analyses.

- Approximately 70-mL aliquots were removed from the 2-L HDPE bottle. After each $70-\mathrm{mL}$ aliquot was prepared, it was divided into one $50-\mathrm{mL}$ and one $20-\mathrm{mL}$ sample and sent to AD Radiochemistry Laboratory for radiochemical separations and analyses. The subsamples were required in order to stay within the dose limits and hood limits for beta radiation.

- Six-mL aliquots of filtered supernate were prepared by filtering aliquots of supernate using a 0.45 micron syringe filter. The filtered supernate samples were then submitted to the AD Wet Chemistry Laboratory for TIC/TOC analyses and Total Base analyses.

- Thirteen-mL aliquots were sent to the AD Dissolution Laboratory for digestion using an aqua regia method. Visual inspection of the digested sample by the AD Task Supervisor indicated that all the solids had dissolved. Aliquots of dissolved slurries were analyzed using inductively coupled plasma-(atomic) emission spectroscopy (ICPES), inductively coupled plasma-mass spectroscopy (ICP-MS), and atomic absorption spectroscopy (AA) for Hg, As, K, Na, and Se.

\subsection{Results and Discussion}

The following tables contain the results for the 2010 Fourth Quarter WAC analyses. Each table provides the analyte of interest, the method used for measuring that analyte, the average concentration of the analyte based on triplicate samples (unless otherwise noted), the \%RSD of the average, and, if applicable, the WAC target or limit for the analyte concentration. Several of the contaminants were either not detected in the slurry samples or detected at values below the method reporting limit (MRL). For those analytes, the result is preceded by a " $<$ " which indicates the result is an upper limit based on the sensitivity of the method used to analyze the individual analyte.

Tables 3-1, 3-2, 3-3 and 3-4 are based directly on attachments 8.1, 8.2, 8.3, and 8.4, respectively, of the WAC. ${ }^{1}$ 
Table 3-1. Results for the 4th Quarter 2010 Tank 50 Slurry Samples for Chemical Contaminants Listed in Attachment 8.1 of the Saltstone WAC.

\begin{tabular}{|c|c|c|c|c|}
\hline Chemical Name & Method & $\frac{\text { Average Concentration }}{(\mathrm{mg} / \mathrm{L})}$ & \% RSD & $\frac{\text { WAC Limit }}{\underline{\text { (mg/L) }}}$ \\
\hline Ammonium $\left(\mathrm{NH}_{4}{ }^{+}\right)$ & IC & $<1.00 \mathrm{E}+02$ & -- & $7.13 E+03$ \\
\hline Carbonate $\left(\mathrm{CO}_{3}^{-2}\right)$ & TIC & $8.10 \mathrm{E}+03$ & 0.18 & $1.45 \mathrm{E}+05$ \\
\hline Chloride (Cl') & IC & $1.39 \mathrm{E}+02$ & 1.10 & $9.68 E+03$ \\
\hline Fluoride (F) & IC & $<1.00 \mathrm{E}+02$ & -- & $4.94 E+03$ \\
\hline Free Hydroxide ( $\left.\mathrm{OH}^{-}\right)$ & Total base & $2.21 \mathrm{E}+04^{\mathrm{a}}$ & 3.52 & $1.91 E+05$ \\
\hline Nitrate $\left(\mathrm{NO}_{3}{ }^{-}\right)$ & IC & $1.24 \mathrm{E}+05$ & 1.24 & $5.29 \mathrm{E}+05$ \\
\hline Nitrite $\left(\mathrm{NO}_{2}^{-}\right)$ & IC & $6.94 \mathrm{E}+03$ & 0.73 & $2.59 \mathrm{E}+05$ \\
\hline Oxalate $\left(\mathrm{C}_{2} \mathrm{O}_{4}{ }^{-2}\right)$ & IC & $1.16 \mathrm{E}+03$ & 0.86 & $3.30 \mathrm{E}+04$ \\
\hline Phosphate $\left(\mathrm{PO}_{4}^{-3}\right)$ & ICP-ES & $5.32 \mathrm{E}+02$ & 4.38 & $3.56 \mathrm{E}+04$ \\
\hline Sulfate $\left(\mathrm{SO}_{4}^{-2}\right)$ & IC & $5.01 \mathrm{E}+03$ & 0.64 & $6.89 \mathrm{E}+04$ \\
\hline Arsenic (As) & AA & $<1.07 \mathrm{E}-01$ & -- & $7.50 \mathrm{E}+02$ \\
\hline Barium (Ba) & ICP-ES & $<5.75 \mathrm{E}-01$ & -- & $7.50 \mathrm{E}+02$ \\
\hline Cadmium (Cd) & ICP-ES & $<8.18 \mathrm{E}-01$ & -- & $3.75 E+02$ \\
\hline Chromium (Cr) & ICP-ES & $4.58 \mathrm{E}+01$ & 2.07 & $1.50 \mathrm{E}+03$ \\
\hline Lead (Pb) & ICP-MS & $2.16 \mathrm{E}-01$ & 12.1 & $7.50 \mathrm{E}+02$ \\
\hline Mercury (Hg) & $\mathrm{AA}$ & $1.08 \mathrm{E}+01$ & 6.01 & $3.25 E+02$ \\
\hline Selenium (Se) & $\mathrm{AA}$ & $<2.14 \mathrm{E}-01$ & -- & $4.50 \mathrm{E}+02$ \\
\hline Silver (Ag) & ICP-ES & $<1.81 \mathrm{E}+00$ & -- & $7.50 \mathrm{E}+02$ \\
\hline Aluminum (Al) & ICP-ES & $2.84 \mathrm{E}+03$ & 1.67 & $1.41 E+05$ \\
\hline n-Butanol & VOA & $<5.00 \mathrm{E}-01^{\mathrm{b}}$ & -- & $2.25 \mathrm{E}+03$ \\
\hline Isobutanol & VOA & $<5.00 \mathrm{E}-01^{\mathrm{b}}$ & -- & $2.25 E+03$ \\
\hline Isopropanol & VOA & $<2.50 \mathrm{E}-01^{\mathrm{b}}$ & -- & $2.25 E+03$ \\
\hline Phenol & SVOA & $<1.00 \mathrm{E}+01^{\mathrm{b}}$ & -- & $7.50 \mathrm{E}+02$ \\
\hline Isopar L & SVOA & $<2.79 \mathrm{E}+01 \mathrm{ppm}^{\mathrm{b}, \mathrm{c}}$ & -- & $1.50 \mathrm{E}+02 \mathrm{ppm}$ \\
\hline Total organic carbon & TOC & $4.47 \mathrm{E}+02$ & 4.37 & $5.00 \mathrm{E}+03$ \\
\hline $\begin{array}{l}\text { Tetraphenylborate } \\
\text { (TPB anion) }\end{array}$ & HPLC & $<5.00 \mathrm{E}+00$ & -- & $7.50 \mathrm{E}+02$ \\
\hline
\end{tabular}

a. Measurement performed on filtered supernate samples.

b. Measurement performed on duplicate samples rather than triplicate samples.

c. Result is calculated from the reported concentration of $<33 \mathrm{mg} / \mathrm{L}$ and the density of the slurry sample listed in Table 3-8. 
Table 3-2. Results for the 4th Quarter 2010 Tank 50 Slurry Samples for Chemical Contaminants Listed in Attachment 8.2 of the Saltstone WAC.

\begin{tabular}{|c|c|c|c|c|}
\hline Chemical Name & Method & $\frac{\text { Average Concentration }}{(\mathrm{mg} / \mathrm{L})}$ & \% RSD & $\frac{\text { WAC TARGET }}{(\mathrm{mg} / \mathrm{L})}$ \\
\hline Boron (B) & ICP-ES & $1.13 \mathrm{E}+02$ & 2.32 & $9.00 \mathrm{E}+02$ \\
\hline Cobalt (Co) & ICP-MS & $<1.64 \mathrm{E}-01$ & -- & $9.00 \mathrm{E}+02$ \\
\hline Copper (Cu) & ICP-ES & $<1.38 \mathrm{E}+00$ & -- & $9.00 \mathrm{E}+02$ \\
\hline Iron (Fe) & ICP-ES & $1.88 \mathrm{E}+02$ & 0.72 & $6.00 \mathrm{E}+03$ \\
\hline Potassium (K) & AA & $1.64 \mathrm{E}+02$ & 3.14 & $3.67 E+04$ \\
\hline Lithium (Li) & ICP-ES & $<7.37 \mathrm{E}+00$ & -- & $9.00 \mathrm{E}+02$ \\
\hline Manganese (Mn) & ICP-ES & $1.33 \mathrm{E}+02$ & 1.36 & $9.00 \mathrm{E}+02$ \\
\hline Molybdenum (Mo) & ICP-ES & $2.95 \mathrm{E}+01$ & 0.23 & $9.00 \mathrm{E}+02$ \\
\hline Nickel (Ni) & ICP-ES & $9.54 \mathrm{E}+00$ & 5.46 & $9.00 \mathrm{E}+02$ \\
\hline Silicon (Si) & ICP-ES & $4.35 \mathrm{E}+01$ & 2.47 & $1.29 \mathrm{E}+04$ \\
\hline Strontium (Sr) & ICP-ES & 8.88E-02 & 4.54 & $9.00 E+02$ \\
\hline Zinc (Zn) & ICP-ES & $5.74 \mathrm{E}+00$ & 1.45 & $9.75 E+02$ \\
\hline Benzene & VOA & $<1.50 \mathrm{E}-01^{\mathrm{a}}$ & -- & $3.75 E+02$ \\
\hline Methanol & VOA & $\mathrm{b}$ & $\mathrm{b}$ & $2.25 E+02$ \\
\hline Toluene & VOA & $<1.50 \mathrm{E}-01^{\mathrm{a}}$ & -- & $3.75 \mathrm{E}+02$ \\
\hline TributylPhosphate (TBP) & SVOA & $<7.50 \mathrm{E}-01^{\mathrm{a}}$ & -- & $3.00 \mathrm{E}+02$ \\
\hline EDTA & HPLC & $<1.00 \mathrm{E}+02$ & -- & $3.75 E+02$ \\
\hline Norpar 13 & SVOA & $<7.50 \mathrm{E}-01^{\mathrm{a}}$ & -- & 1.00E-01 \\
\hline
\end{tabular}

a. Measurement performed on duplicate samples rather than triplicate samples.

b. Currently, a routine method for detecting this species does not exist in AD.

As indicated in Tables 3-1 and 3-2, all of the contaminants are within the WAC limits with the exception of Norpar 13. In October 2010, AD reviewed the MRL's for the organic constituents in Tank 50. All of the MRL's are at or below the WAC limits for the organics with the exception of Norpar 13 which has an MRL of $0.75 \mathrm{mg} / \mathrm{L}$, which is above the WAC limit. ${ }^{4}$ Isopar L and Norpar 13 have negligible solubility in aqueous solutions, which makes it difficult to obtain reliable subsamples of the original sample. The values reported in these tables are the concentrations as detected by the GC/MS but may not necessarily be an accurate representation of the concentrations of these analytes in Tank 50. 
Table 3-3. Results for 4th Quarter 2010 Tank 50 Slurry Samples and WAC Limits for Radionuclide Contaminants Listed in Attachment 8.3 of the Saltstone WAC.

\begin{tabular}{|c|c|c|c|c|}
\hline$\underline{\text { Radionuclide }}$ & Method & $\frac{\begin{array}{c}\text { Average } \\
\text { Concentration }\end{array}}{\text { (pCi/mL) }}$ & \% RSD & $\frac{\text { WAC LIMIT }}{(\mathrm{pCi} / \mathrm{mL})}$ \\
\hline Tritium $\left({ }^{3} \mathbf{H}\right)$ & Tritium counting & $4.77 \mathrm{E}+02$ & 2.54 & $5.63 E+05$ \\
\hline Carbon-14 $\left({ }^{14} \mathrm{C}\right)$ & C-14 Liquid scintillation & $1.40 \mathrm{E}+02$ & 5.20 & $1.13 E+05$ \\
\hline Nickel-63 $\left({ }^{63} \mathrm{Ni}\right)$ & $\mathrm{Ni}-59 / 63$ & $3.76 \mathrm{E}+02$ & 78.4 & $1.13 E+05$ \\
\hline Strontium-90 $\left({ }^{90} \mathrm{Sr}\right)$ & Sr-90 Liquid scintillation & $8.36 \mathrm{E}+04$ & 5.42 & $2.25 \mathrm{E}+07$ \\
\hline Technetium-99 $\left({ }^{99} \mathrm{Tc}\right)$ & Tc-99 Liquid scintillation & $2.75 \mathrm{E}+04$ & 1.49 & $4.22 E+05$ \\
\hline Iodine-129 $\left({ }^{129} \mathrm{I}\right)$ & $\begin{array}{l}\text { I-129 (w/ separation) } \\
\text { Liquid scintillation }\end{array}$ & $5.74 \mathrm{E}+00$ & 18.0 & $1.13 E+03$ \\
\hline Cesium-137 ( $\left.{ }^{137} \mathrm{Cs}\right)$ & Gamma Scan & $5.54 \mathrm{E}+06$ & 2.93 & $4.75 \mathrm{E}+07$ \\
\hline Uranium-233 $\left({ }^{233} U\right)$ & ICP-MS & $<3.77 \mathrm{E}+02$ & -- & $1.13 E+04$ \\
\hline Uranium-235 $\left({ }^{235} \mathrm{U}\right)$ & ICP-MS & 3.99E-01 & 6.95 & $1.13 E+02$ \\
\hline $\begin{array}{l}\text { Plutonium-241 } \\
\left({ }^{241} \mathrm{Pu}\right)\end{array}$ & $\begin{array}{l}\text { Pu238/241 Liquid } \\
\text { scintillation }\end{array}$ & $1.13 \mathrm{E}+04$ & 22.4 & $8.38 E+05$ \\
\hline Total Alpha & $\begin{array}{l}\text { Liquid Scintillation } \\
\text { Counting }\end{array}$ & $3.22 E+04$ & 5.96 & $2.50 \mathrm{E}+05$ \\
\hline
\end{tabular}

None of the radionuclide contaminants in Table 3-3 exceed the WAC limit.

Table 3-4. Results for 4th Quarter 2010 Tank 50 Slurry Samples and WAC Targets for Radionuclide Contaminants Listed in Attachment 8.4 of the Saltstone WAC.

\begin{tabular}{|c|c|c|c|c|}
\hline$\underline{\text { Radionuclide }}$ & Method & $\frac{\text { Average Concentration }}{\underline{(\mathrm{pCi} / \mathbf{m L})}}$ & \%RSD & $\frac{\text { WAC }}{\text { TARGET }}$ \\
\hline Sodium-22 ( $\left.{ }^{22} \mathrm{Na}\right)$ & $\begin{array}{l}\text { Gamma scan } \\
\text { (Cs removed) }\end{array}$ & $<2.38 \mathrm{E}+00$ & -- & $1.25 E+04$ \\
\hline Aluminum-26 $\left({ }^{26} \mathrm{Al}\right)$ & $\begin{array}{l}\text { Gamma scan } \\
\text { (Cs removed) }\end{array}$ & $<9.41 \mathrm{E}-02$ & -- & $2.88 E+03$ \\
\hline Cobalt-60 $\left({ }^{60} \mathrm{Co}\right)$ & $\begin{array}{l}\text { Gamma scan } \\
\text { (Cs removed) }\end{array}$ & $7.69 \mathrm{E}+00$ & 2.37 & $1.13 E+06$ \\
\hline Nickel-59 $\left({ }^{59} \mathrm{Ni}\right)$ & $\mathrm{Ni}-59 / 63$ & $<2.48 \mathrm{E}-01$ & -- & $1.13 E+05$ \\
\hline Selenium-79 $\left({ }^{79} \mathrm{Se}\right)$ & Se79 & $3.07 \mathrm{E}+02$ & 45.1 & $1.90 \mathrm{E}+04$ \\
\hline Niobium-93m $\left({ }^{93 m} \mathrm{Nb}\right)$ & ICP-MS & $3.16 \mathrm{E}+02$ & 4.73 & $2.85 E+06$ \\
\hline Niobium-94 $\left({ }^{94} \mathrm{Nb}\right)$ & $\begin{array}{l}\text { Gamma scan } \\
\text { (Cs removed) }\end{array}$ & $<3.84 \mathrm{E}-01$ & -- & $1.53 E+04$ \\
\hline Molybdenum-93 $\left({ }^{93} \mathrm{Mo}\right)$ & ICP-MS & $1.42 \mathrm{E}+05$ & 4.73 & $1.18 \mathrm{E}+07$ \\
\hline Ruthenium-106 $\left({ }^{106} \mathrm{Ru}\right)$ & $\begin{array}{l}\text { Gamma scan } \\
\text { (Cs removed) }\end{array}$ & $<3.43 \mathrm{E}+00$ & -- & $1.13 E+06$ \\
\hline Antimony-125 ( $\left({ }^{125} \mathrm{Sb}\right)$ & $\begin{array}{l}\text { Gamma scan } \\
\text { (Cs removed) }\end{array}$ & $6.76 \mathrm{E}+03$ & 2.00 & $2.25 E+06$ \\
\hline $\operatorname{Tin}-126\left({ }^{126} \mathrm{Sn}\right)$ & $\begin{array}{l}\text { Gamma scan } \\
\text { (Cs removed) }\end{array}$ & $1.05 \mathrm{E}+02$ & 1.96 & $1.80 \mathrm{E}+04$ \\
\hline Cesium-134 ( $\left.{ }^{134} \mathrm{Cs}\right)$ & Gamma Scan & $<5.77 \mathrm{E}+02$ & -- & $1.13 E+06$ \\
\hline
\end{tabular}


Table 3-4 (continued). Results for 4th Quarter 2010 Tank 50 Slurry Samples and WAC Targets for Radionuclide Contaminants Listed in Attachment 8.4 of the Saltstone WAC.

\begin{tabular}{|c|c|c|c|c|}
\hline$\underline{\text { Radionuclide }}$ & Method & $\frac{\text { Average Concentration }}{\underline{(\mathrm{pCi} / \mathrm{mL})}}$ & \%RSD & $\frac{\frac{\text { WAC }}{\text { TARGET }}}{(\mathrm{pCi} / \mathrm{mL})}$ \\
\hline Cesium-135 ( $\left.{ }^{135} \mathrm{Cs}\right)$ & ICP-MS & $4.22 \mathrm{E}+01$ & 13.2 & $1.13 E+06$ \\
\hline Cerium-144 $\left({ }^{144} \mathrm{Ce}\right)$ & $\begin{array}{c}\text { Gamma scan } \\
\text { (Cs removed) }\end{array}$ & $<5.63 \mathrm{E}+00$ & -- & $1.13 E+05$ \\
\hline Promethium-147 ( $\left.{ }^{147} \mathrm{Pm}\right)$ & $\begin{array}{l}\text { Pm147/Sm151 } \\
\text { Liquid } \\
\text { scintillation }\end{array}$ & $<6.17 \mathrm{E}+02$ & -- & $5.63 E+06$ \\
\hline Samarium-151 $\left({ }^{151} \mathrm{Sm}\right)$ & $\begin{array}{l}\text { Pm147/Sm151 } \\
\text { Liquid } \\
\text { scintillation } \\
\end{array}$ & $<5.09 \mathrm{E}+02$ & -- & $2.25 E+04$ \\
\hline Europium-152 ( ${ }^{152}$ Eu) & $\begin{array}{l}\text { Gamma scan } \\
\text { (Cs removed) }\end{array}$ & $<8.83 \mathrm{E}-01$ & -- & $7.28 \mathrm{E}+01$ \\
\hline Europium-154 $\left({ }^{154} \mathrm{Eu}\right)$ & $\begin{array}{l}\text { Gamma scan } \\
\text { (Cs removed) }\end{array}$ & $3.23 \mathrm{E}+02$ & 4.61 & $2.25 E+06$ \\
\hline Europium-155 $\left({ }^{155} \mathrm{Eu}\right)$ & $\begin{array}{l}\text { Gamma scan } \\
\text { (Cs removed) }\end{array}$ & $<4.39 \mathrm{E}+01$ & -- & 1.13E+04 \\
\hline Radium-226 ( $\left.{ }^{226} \mathrm{Ra}\right)$ & $\begin{array}{l}\text { Gamma scan } \\
\text { (Cs removed) }\end{array}$ & $<1.95 \mathrm{E}+01$ & -- & 7.97E+03 \\
\hline Thorium-229 $\left({ }^{229} \mathrm{Th}\right)$ & ICP-MS & $<4.97 \mathrm{E}+03$ & -- & $1.63 E+05$ \\
\hline Thorium-230 $\left({ }^{230} \mathrm{Th}\right)$ & ICP-MS & $<6.57 \mathrm{E}+02$ & -- & $6.26 \mathrm{E}+03$ \\
\hline Thorium-232 $\left({ }^{232} \mathrm{Th}\right)$ & ICP-MS & $9.47 \mathrm{E}-03^{\mathrm{a}}$ & -- & $2.88 E+03$ \\
\hline Uranium-232 $\left({ }^{232} \mathrm{U}\right)$ & $\mathrm{U} 232$ & $5.82 \mathrm{E}+00$ & 38.2 & $1.71 \mathrm{E}+05$ \\
\hline Uranium-234 $\left({ }^{234} U\right)$ & ICP-MS & $<9.74 \mathrm{E}+01$ & -- & $1.13 E+04$ \\
\hline Uranium-236 $\left({ }^{236} \mathrm{U}\right)$ & ICP-MS & $1.56 \mathrm{E}+00$ & 0.24 & 1.13E+04 \\
\hline Uranium-238 $\left({ }^{238} \mathrm{U}\right)$ & ICP-MS & $1.64 \mathrm{E}+00$ & 1.49 & $1.13 E+04$ \\
\hline Neptunium-237 ( $\left.{ }^{237} \mathrm{~Np}\right)$ & ICP-MS & $<1.10 \mathrm{E}+01$ & -- & $2.50 \mathrm{E}+05$ \\
\hline Plutonium-238 $\left({ }^{238} \mathrm{Pu}\right)$ & $\begin{array}{c}\text { Pu238/241 } \\
\text { Pu alpha PHA }\end{array}$ & $2.98 \mathrm{E}+04$ & 20.6 & $2.50 \mathrm{E}+05$ \\
\hline Plutonium-239 $\left({ }^{239} \mathrm{Pu}\right)$ & $\begin{array}{c}\text { Pu238/241 } \\
\text { Pu alpha PHA }\end{array}$ & $1.97 \mathrm{E}+03$ & 55.3 & $2.50 \mathrm{E}+05$ \\
\hline Plutonium-240 ( $\left.{ }^{240} \mathrm{Pu}\right)$ & $\begin{array}{c}\text { Pu238/241 } \\
\text { Pu alpha PHA }\end{array}$ & $1.97 \mathrm{E}+03$ & 55.3 & $2.50 \mathrm{E}+05$ \\
\hline Plutonium-242 ( $\left({ }^{242} \mathrm{Pu}\right)$ & ICP-MS & $<5.95 \mathrm{E}+01$ & -- & $2.50 \mathrm{E}+05$ \\
\hline Plutonium-244 ( $\left({ }^{244} \mathrm{Pu}\right)$ & ICP-MS & $<2.76 \mathrm{E}-01$ & -- & $7.02 E+04$ \\
\hline Americium-241 ( $\left.{ }^{241} \mathrm{Am}\right)$ & $\begin{array}{l}\text { Gamma scan } \\
\text { (Cs removed) }\end{array}$ & $1.18 \mathrm{E}+03$ & 4.85 & $2.50 \mathrm{E}+05$ \\
\hline Americium-242m $\left({ }^{242 m} \mathrm{Am}\right)$ & $\mathrm{Am} / \mathrm{Cm}$ & $3.45 \mathrm{E}-01^{\mathrm{a}}$ & 41.2 & 3.68E-01 \\
\hline Americium-243 ( $\left.{ }^{243} \mathrm{Am}\right)$ & $\mathrm{Am} / \mathrm{Cm}$ & $1.52 \mathrm{E}+01$ & 29.8 & $2.50 \mathrm{E}+05$ \\
\hline Curium-242 ( $\left.{ }^{242} \mathrm{Cm}\right)$ & $\mathrm{Am} / \mathrm{Cm}$ & $2.86 \mathrm{E}-01^{\mathrm{a}}$ & 41.2 & $1.13 E+04$ \\
\hline Curium-244 $\left({ }^{244} \mathrm{Cm}\right)$ & $\mathrm{Am} / \mathrm{Cm}$ & $2.68 \mathrm{E}+03$ & 18.0 & $2.50 \mathrm{E}+05$ \\
\hline Curium-245 $\left({ }^{245} \mathrm{Cm}\right)$ & $\mathrm{Am} / \mathrm{Cm}$ & $<1.14 \mathrm{E}+01$ & -- & $2.25 \mathrm{E}+05$ \\
\hline
\end{tabular}

a. Result is from a single measurement 
As shown in Table 3-4, none of the radionuclide contaminants exceed the targets listed in the latest revision of the WAC. In a memo from LWO, the requested detection limits for several radionuclides were lowered in order to accommodate future inventory reporting requirements. ${ }^{2}$ The reported limit of ${ }^{94} \mathrm{Nb}$ is above the limit requested by LWO $(2.00 \mathrm{E}-03 \mathrm{pCi} / \mathrm{mL}){ }^{2}$ however, the reported limit is below the limit set by $\mathrm{AD} .^{3}$

The values for ${ }^{93 \mathrm{~m}} \mathrm{Nb}$ and ${ }^{93} \mathrm{Mo}$ in Table 3-4 are estimated from the ICP-MS result for mass 93. The entire signal at mass 93 is assigned to ${ }^{93} \mathrm{Zr}$, and since it is in secular equilibrium with ${ }^{93 \mathrm{~m}} \mathrm{Nb}$, the maximum activity of the ${ }^{93 \mathrm{~m}} \mathrm{Nb}$ is equal to that of the ${ }^{93} \mathrm{Zr}$. The specific activity of ${ }^{93} \mathrm{Zr}$ (2.51E-03 Ci/g) is used when calculating the activity concentration of ${ }^{93 \mathrm{~m}} \mathrm{Nb}$. Similarly, ${ }^{93} \mathrm{Mo}$ is estimated by assigning all of mass 93 to ${ }^{93} \mathrm{Mo}$ and using the specific activity of ${ }^{93} \mathrm{Mo}$ to calculate the concentration. The concentration of ${ }^{135} \mathrm{Cs}$ is calculated by assigning all of the mass at 135 to cesium. ${ }^{126} \mathrm{Sn}$ and ${ }^{126} \mathrm{Sb}$ are in secular equilibrium for this sample; therefore their activities are equal. As a result, the measured activity of ${ }^{126} \mathrm{Sb}$ was used for the ${ }^{126} \mathrm{Sn}$ concentration since ${ }^{126} \mathrm{Sb}$ was detected and ${ }^{126} \mathrm{Sn}$ was below the MDL. Since no analyte was detected at mass 229 and because the ${ }^{229} \mathrm{Th}$ and ${ }^{230} \mathrm{Th}$ isotopes have identical electronic structures, the MDL measured for ${ }^{230} \mathrm{Th}$ was used for the MDL for ${ }^{229} \mathrm{Th}$. The activity concentrations are then calculated from the specific activities for ${ }^{229} \mathrm{Th}$ and ${ }^{230} \mathrm{Th}$. It is assumed all the mass detected at mass 244 is ${ }^{244} \mathrm{Pu}$. The $\mathrm{Pu}$ alpha Pulse Height Analysis (PHA) method does not resolve the alpha activities of ${ }^{239} \mathrm{Pu}$ and ${ }^{240} \mathrm{Pu}$. To determine the maximum concentration of each radionuclide, the total activity is assigned to each radionuclide separately. As shown in Table 3-4, the reported activity is below the WAC limit for each radionuclide.

Tables 3-5 and 3-6 list the chemical contaminants that impact vault flammability. These chemicals must be monitored to ensure flammable gases do not contribute more than $10 \%$ of the Composite Lower Flammability Limit (CLFL). ${ }^{1}$

Table 3-5. Results for the 4th Quarter 2010 Tank 50 Slurry Samples for Acceptance Criteria Limits for Chemical Contaminants Impacting Vault Flammability, Listed in Table 3 of the Saltstone WAC.

\begin{tabular}{|l|c|c|c|c|}
\hline Chemical Name & $\underline{\text { Method }}$ & $\frac{\text { Average Concentration }}{\underline{\mathbf{m g} / \mathbf{L})}}$ & $\underline{\text { \% RSD }}$ & WAC Limit \\
\hline Isopar L & SVOA & $<2.79 \mathrm{E} 0+01 \mathrm{ppm}^{\mathrm{a}}$ & -- & $\mathbf{1 . 1 0 E + 0 1 ~ \mathbf { ~ p m m }}$ \\
\hline $\begin{array}{l}\text { Tetraphenylborate } \\
\text { (TPB anion) }\end{array}$ & HPLC & $<5.00 \mathrm{E}+00$ & -- & $\begin{array}{c}\mathbf{5 . 0 0 E}+00 \\
\mathbf{m g} / \mathbf{L}\end{array}$ \\
\hline Ammonium $\left(\mathbf{N H}_{4}{ }^{+}\right)$ & IC & $<1.00 \mathrm{E}+02$ & -- & $\begin{array}{c}\mathbf{2 . 1 2 E}+\mathbf{0 2} \\
\mathbf{m g} / \mathbf{L}\end{array}$ \\
\hline
\end{tabular}

a. Result is calculated from the reported concentration of $<33 \mathrm{mg} / \mathrm{L}$ and the density of the slurry sample.

Table 3-6. Results for the 4th Quarter 2010 Tank 50 Slurry Samples for Concentrations of "Other Organics” Impacting Vault Flammability, Listed in Table 4 of the Saltstone WAC.

\begin{tabular}{|l|c|c|c|c|}
\hline Chemical Name & $\underline{\text { Method }}$ & $\frac{\text { Average Concentration }}{\underline{\mathbf{m g} / \mathbf{L})}}$ & $\underline{\text { \% RSD }}$ & $\begin{array}{c}\underline{\text { WAC }} \\
\text { Concentrations }\end{array}$ \\
\hline n-Butanol & VOA & $<5.00 \mathrm{E}-01$ & -- & $\mathbf{0 . 7 5} \mathbf{~ m g} / \mathbf{L}$ \\
\hline Tributylphosphate & SVOA & $<7.50 \mathrm{E}-01$ & -- & $\mathbf{1 . 0} \mathbf{~ m g / L}$ \\
\hline Isopropanol & VOA & $<2.50 \mathrm{E}-01$ & -- & $\mathbf{0 . 2 5} \mathbf{~ m g / L}$ \\
\hline Methanol & a & a & -- & $\mathbf{0 . 2 5} \mathbf{~ m g / L}$ \\
\hline Norpar 13 & SVOA & $<7.50 \mathrm{E}-01$ & -- & $\mathbf{0 . 1} \mathbf{~ m g / L}$ \\
\hline
\end{tabular}

a. $\quad$ Currently, a routine method for detecting this species does not exist in AD. 
None of the species considered in Tables 3-5 or 3-6 are above the WAC limit with the exception of Isopar L and Norpar 13, respectively. Although the reported detection limit for Isopar L is greater than the WAC limit for vault flammability, it is below the WAC limits for accident analysis as shown in Table 3-1. It should be noted that the detection limit for Isopar L was expected based on current AD capabilities as documented in the TTQAP. ${ }^{6}$ The reported detection limit for Norpar is above the WAC limit for both accident analysis (Table 3-1) and vault flammability (Table 3-6) but it is the lowest achievable MRL for this analyte. ${ }^{4}$ As previously discussed, the insolubility of Isopar L and Norpar 13 makes sub-sampling difficult, therefore the reported results are not necessarily representative of the concentration of these analytes in the Tank 50 sample received by SRNL.

The samples submitted for SVOA analysis contained an estimated concentration $(2.25 \mathrm{mg} / \mathrm{L})$ of trimethylbenzene, which is a tentatively identifiable compound (TIC) per EPA Method 8270.* Trimethylbenzene is not included in the WAC, but it is a flammable organic that can contribute to the CLFL for the Saltstone vault. Since it is a TIC, there is approximately $75 \%$ uncertainty associated with the reported concentration. In an effort to further investigate the presence of trimethylbenzene, three separate steel samplers containing additional Tank 50 material were submitted for SVOA analyses. Trimethylbenzene was not detected in any of the additional 4Q10 samples. ${ }^{8}$

Table 3-7 provides results for the processing criteria for transfers into the Saltstone Facility.

Table 3-7. Results for the 4th Quarter 2010 Tank 50 Slurry Samples for Saltstone Processing Criteria WAC Limits, Listed in Table 5 of the Saltstone WAC.

\begin{tabular}{|l|c|c|c|}
\hline Processing Criterion & Method & Value & \%RSD \\
\hline $\mathbf{p H}>\mathbf{1 0}$ & Calculated & $>13$ & - \\
\hline $\mathbf{2 . 5} \mathbf{M}<\left[\mathbf{N a}^{+}\right]<\mathbf{7 . 0} \mathbf{M}$ & AA/ICP-ES & $3.91 \mathrm{M}$ & 6.04 \\
\hline $\begin{array}{l}\text { Total Insoluble Solids }<\mathbf{1 5} \\
\mathbf{w t} \%\end{array}$ & Calculated & $1.224 \mathrm{wt} \%$ & $15.95^{\mathrm{a}}$ \\
\hline
\end{tabular}

a. This is the 95\% uncertainty calculated from the measured results for the Wt \% total solids and Wt \% dissolved solids in triplicate samples of the slurry.

All of the results contained in Table 3-7 fall within the general processing criteria. The $\mathrm{pH}$ was calculated using the free base concentration $\left(\mathrm{OH}^{-}\right)$. The value for the total insoluble solids was calculated by Engineering Process Development of SRNL from experimentally determined values for total solids and dissolved solids in the slurry supernate.

Table 3-8 provides constituents listed in the Technical Task Request but not contained in the WAC.

\footnotetext{
* EPA manual SW-846 method 8270 defines a TIC as an analyte that has been positively identified using GC/MS but for which there is not a calibration standard. For samples containing components not associated with the calibration standards, a library search may be made for the purpose of tentative identification. The concentration is estimated from the peak area and the closest internal standard.
} 
Table 3-8. Requests for Constituents for TCLP/UHC Support as well as from the TTR for Tank 50 Slurry Samples; Results Not Contained in Previous Tables.

\begin{tabular}{|l|c|c|c|}
\hline Constituent & $\underline{\text { Method }}$ & $\begin{array}{c}\text { Average Value } \\
\text { (mg/L, unless stated otherwise) }\end{array}$ & $\underline{\text { \%RSD }}$ \\
\hline Antimony (Sb) & ICP-ES & $<6.70 \mathrm{E}+00$ & -- \\
\hline Beryllium (Be) & ICP-ES & $<1.07 \mathrm{E}-01$ & -- \\
\hline Cyanide (CN) & a. & a. & -- \\
\hline Thallium (Tl) & ICP-MS & $<8.26 \mathrm{E}-02$ & -- \\
\hline Density (slurry) & Measured $\left(25.5^{\circ} \mathrm{C}\right)$ & $1.1823 \mathrm{~g} / \mathrm{mL}$ & 0.60 \\
\hline Total Beta & LSC & $6.89 \mathrm{E}+06 \mathrm{pCi} / \mathrm{mL}$ & 3.00 \\
\hline Total Solids & Measured & $23.07 \%$ & 0.18 \\
\hline
\end{tabular}

a. Currently, a routine method for detecting this species does not exist in AD.

The results from Table 3-8 are used in a series of calculations performed by the SRNL Engineering Process Development group to support TCLP/UHC testing by a certified laboratory. ${ }^{9}$ The density of the slurry was measured at $25.5^{\circ} \mathrm{C}$. An estimate of the maximum concentration of the natural nonradioactive element $\mathrm{Tl}$ in the sample could only be determined by measuring the detection limits for Tl using ICP-MS. Natural Tl is composed of two isotopes, ${ }^{203} \mathrm{Tl}$ and ${ }^{205} \mathrm{Tl}$ with fraction abundances of 0.295 and 0.705 , respectively. The concentration of each isotope was divided by its fractional abundance and the reported detection limit of $\mathrm{Tl}$ is the average of the lowest value for each of the two isotopes.

The tank corrosion species listed in Table 3-9 were requested by Waste Solidification Engineering (WSE). ${ }^{*}$ Specific gravity was calculated by dividing the measured density of the slurry (given in Table $3-8$ at $25.5^{\circ} \mathrm{C}$ ) by the density of water at the same temperature. ${ }^{10}$

Table 3-9. Requests from the WSE for Corrosion Species from Tank 50 Slurry Samples; Results Not Contained in Previous Tables.

\begin{tabular}{|l|c|c|c|}
\hline Constituent & $\underline{\text { Method }}$ & $\underline{\text { Average Value }}$ & $\underline{\text { \%RSD }}$ \\
\hline Specific Gravity & a & 1.1860 & -- \\
\hline Ba-137m & b & $5.24 \mathrm{E}+06 \mathrm{pCi} / \mathrm{mL}$ & 2.93 \\
\hline Total Gamma & c & $5.25 \mathrm{E}+06 \mathrm{pCi} / \mathrm{mL}$ & -- \\
\hline
\end{tabular}

a. Calculated from the measured density of slurry and density of water at $25.5{ }^{\circ} \mathrm{C}^{10}$.

b. Calculated from the measured concentration of Cs-137.

c. Calculated from the sum of measured gamma emitters.

The radionuclide ${ }^{137 \mathrm{~m}} \mathrm{Ba}$ is the radioactive daughter of $94.6 \%$ of the beta decay of ${ }^{137} \mathrm{Cs} .5 .3 \%$ of the ${ }^{137} \mathrm{Cs}$ decays to stable ${ }^{137 \mathrm{~m}} \mathrm{Ba}$. The half-life the parent radionuclide, ${ }^{137} \mathrm{Cs}$, is $5 \mathrm{x}$ that of the daughter, ${ }^{137 \mathrm{~m}} \mathrm{Ba}$, therefore the two radionuclides are in secular equilibrium. Radionuclides in secular equilibrium have the same activity associated with decay. Thus the activity of ${ }^{137 \mathrm{~m}} \mathrm{Ba}$ is $94.6 \%$ of the activity of the ${ }^{137} \mathrm{Cs}$ or $5.24 \mathrm{E}+06 \mathrm{pCi} / \mathrm{mL}$. The activities calculated for total gamma and ${ }^{137 \mathrm{~m}} \mathrm{Ba}$ are expected to be close for this sample because the total gamma activity is dominated

* Requested in an electronic mail message from S. D. Hevel on December 20, 2007. (See page 30 of WSRC-NB-200700189.) 
by ${ }^{137 \mathrm{~m}} \mathrm{Ba}$, the radioactive daughter of ${ }^{137} \mathrm{Cs}$. The total gamma activity was calculated by summing the measured gamma activity of the major gamma emitters: ${ }^{60} \mathrm{Co},{ }^{125} \mathrm{Sb},{ }^{126} \mathrm{Sn},{ }^{137} \mathrm{Cs}$ (via ${ }^{137 \mathrm{~m}} \mathrm{Ba}$ ), ${ }^{154} \mathrm{Eu}$, and ${ }^{241} \mathrm{Am}$.

Table 3-10 provides results for additional radionuclides not listed in the WAC but which now require quantification in order to support inventory reporting requirements.

Table 3-10. Additional Radionuclides Requested for Inventory Reporting Requirements.

\begin{tabular}{|c|c|c|c|c|}
\hline$\underline{\text { Radionuclide }}$ & Method & $\frac{\text { Average Concentration }}{\underline{(\mathbf{p C i} / \mathbf{m L})}}$ & \%RSD & $\frac{\text { REQUESTED }}{\frac{\text { TARGET }}{\text { (pCi/mL) }}}$ \\
\hline Potassium-40 $\left({ }^{40} \mathrm{~K}\right)$ & $\begin{array}{l}\text { Gamma scan } \\
\text { (Cs removed) }\end{array}$ & $<3.01 \mathrm{E}+00$ & -- & $1.00 \mathrm{E}+04$ \\
\hline Silver-108m $\left({ }^{108 m} \mathrm{Ag}\right)$ & $\begin{array}{l}\text { Gamma scan } \\
\text { (Cs removed) }\end{array}$ & $<1.17 \mathrm{E}+00$ & -- & $1.00 \mathrm{E}+04$ \\
\hline Barium-133 ( $\left.{ }^{133} \mathbf{B a}\right)$ & $\begin{array}{l}\text { Gamma scan } \\
\text { (Cs removed) }\end{array}$ & $<2.69 \mathrm{E}+00$ & -- & $1.00 \mathrm{E}+04$ \\
\hline Bismuth-207 $\left({ }^{207} \mathrm{Bi}\right)$ & $\begin{array}{l}\text { Gamma scan } \\
\text { (Cs removed) }\end{array}$ & $<9.28 \mathrm{E}-01$ & -- & $1.00 \mathrm{E}+04$ \\
\hline Actinium-227 $\left({ }^{227} \mathrm{Ac}\right)$ & $\begin{array}{l}\text { Gamma scan } \\
\text { (Cs removed) }\end{array}$ & $<2.73 \mathrm{E}+01$ & -- & $1.00 \mathrm{E}+04$ \\
\hline Radium-228 ( $\left.{ }^{228} \mathrm{Ra}\right)$ & $\begin{array}{l}\text { Gamma scan } \\
\text { (Cs removed) }\end{array}$ & $<2.59 \mathrm{E}+00$ & -- & $1.00 \mathrm{E}+04$ \\
\hline Thorium-228 $\left({ }^{228} \mathrm{Th}\right)$ & $\begin{array}{l}\text { Gamma scan } \\
\text { (Cs removed) }\end{array}$ & $<4.24 \mathrm{E}+01$ & -- & $1.00 \mathrm{E}+04$ \\
\hline Protactinium-231 $\left({ }^{231} \mathrm{~Pa}\right)$ & $\begin{array}{l}\text { Gamma scan } \\
\text { (Cs removed) }\end{array}$ & $<6.67 \mathrm{E}+01$ & -- & $1.00 \mathrm{E}+04$ \\
\hline Curium-247 $\left({ }^{247} \mathrm{Cm}\right)$ & $\mathrm{Am} / \mathrm{Cm}$ & $<1.20 \mathrm{E}+01$ & -- & 1.43E-11 \\
\hline Californium-249 $\left({ }^{249} \mathrm{Cf}\right)$ & $\mathrm{Am} / \mathrm{Cm}$ & $<1.27 \mathrm{E}+01$ & -- & $1.33 \mathrm{E}-10$ \\
\hline Californium-251 $\left({ }^{251} \mathrm{Cf}\right)$ & $\mathrm{Am} / \mathrm{Cm}$ & $<1.04 \mathrm{E}+01$ & -- & $1.00 \mathrm{E}+02$ \\
\hline
\end{tabular}

As shown in Table $3-10,{ }^{247} \mathrm{Cm}$ and ${ }^{249} \mathrm{Cf}$ surpass the LWO requested targets. ${ }^{2}$ However, the reported detection limits are below the detection limits established by AD. 3,6 


\subsection{Conclusions}

The following conclusions are drawn from the analytical results provided in this report:

- The concentrations of the reported chemical and radioactive contaminants were less than their respective WAC targets or limits unless noted in this section.

- The reported detection limits for ${ }^{94} \mathrm{Nb},{ }^{247} \mathrm{Cm}$ and ${ }^{249} \mathrm{Cf}$ are above the requested limits from Reference 2. However, they are below the limits established in Reference 3.

- There is an estimated concentration of trimethylbenzene $(2.25 \mathrm{mg} / \mathrm{L})$. This is not a WAC analyte, but it is the first time this organic compound has been detected in a quarterly WAC sample from Tank 50.

- The reported detection limit ${ }^{4}$ for Norpar 13 is greater than the limit from Table 4 and Attachment 8.2 of the WAC ${ }^{1}$.

- The reported detection limit for Isopar L is greater than the limit from Table 3 of the $\mathrm{WAC}^{1}$.

- Isopar L and Norpar 13 have limited solubility in aqueous solutions making it difficult to obtain consistent and reliable sub-samples. The values reported in this memo are the concentrations in the sub-sample as detected by the GC/MS; however, the results may not accurately represent the concentrations of the analytes in Tank 50. 
SRNL-STI-2010-00713

Revision 0

\subsection{References}

1. Ray, J.W., "Waste Acceptance Criteria for Aqueous Waste Sent to the Z-Area Saltstone Production Facility (U)," Savannah River Site, X-SD-Z-00001, Rev. 9, September 2009.

2. Staub, A.V., "Minimum Detection Limits for Saltstone Quarterly WAC Analyses," Savannah River Site, LWO-WSE-2009-00163, June 2009.

3. DiPrete, C.C., "Overview of Capability to Measure Radionuclides of Interest for Saltstone," Savannah River National Laboratory, SRNL-L4000-2009-00028, June 2009.

4. Crump, S.L., "Determination of Method Reporting Limits for Select Analytes by GC/MS," Savannah River National Laboratory, Aiken, SC, SRNL-TR-2010-00206, Rev. 0, October 13, 2010.

5. Staub, A.V., "Saltstone Formulation, Quarterly Analysis, TCLP Preparation - Jan to Oct 2010," Savannah River Site, HLW-SSF-TTR-2010-0001, Rev. 0, January 2010.

6. Reigel, M.M., "Task Technical and Quality Assurance Plan for the Tank 50 Waste Acceptance Criteria (WAC) Analyses," Savannah River National Laboratory, SRNL-RP2009-01467, Revision 0, February 2010.

7. Reigel, M.M. and Bibler, N.E., "Tables Containing Results for the Fourth Quarter 2010 Tank 50 WAC Slurry Sample: Chemical and Radionuclide Contaminant Results," Savannah River National Laboratory, Aiken, SC, SRNL-L3100-2010-00225 Rev. 0, December 14, 2010.

8. $\quad$ Reigel, M.M., "Results from the November 11, 2010 Tank 50H Slurry Samples: SVOA Analytes," Savannah River National Laboratory, Aiken, SC, SRNL-L3100-2011-00018, February 2, 2011.

9. $\quad$ Reigel, M.M., "Task Technical and Quality Assurance Plan for SRNL Support of TCLP Preparation and Analysis for Saltstone," Savannah River National Laboratory, Aiken, SC, SRNL-RP-2010-00101, February 2010.

10. Handbook of Chemistry and Physics, 90th ed.; pp. 6-4. Edited by Lide, D.R. CRC Press, Boca Raton, Fl, 2009. 